\title{
Corporate Governance, Firm Performance and Capital Structure: Evidence From Indonesia
}

\author{
M. Chabachib ${ }^{1}$, Bahrain Pasha Irawan ${ }^{1}$, H. Hersugondo ${ }^{1}$, Riskin Hidayat ${ }^{2} \&$ Imang Dapit Pamungkas ${ }^{3}$ \\ ${ }^{1}$ Faculty of Economics and Business, Diponegoro University, Semarang, Indonesia \\ ${ }^{2}$ STIE YPPI, Rembang, Indonesia \\ ${ }^{3}$ Dian Nuswantoro University, Semarang, Indonesia \\ Corespondence: H. Hersugondo, Associate Professor, Faculty of Economics and Business, Diponegoro University, \\ Semarang, Indonesia. E-mail: hersugondo@lecturer.undip.ac.id
}

Received: December 24, 2019

Accepted: January 29, 2020

Online Published: March 5, 2020

doi:10.5430/rwe.v11n1p48

URL: https://doi.org/10.5430/rwe.v11n1p48

\begin{abstract}
This study aims to examine the good corporate governance which is proxied with managerial ownership, the proportion of independent board of commissioners, the size of the board of directors and institutional ownership of corporate performance through capital structure. The sample is a non-financial corporation listed on the Indonesia Stock Exchange in 2018 and obtained the number of samples as many as 120. The analysis tool uses a path analysis. The results show that managerial ownership, the proportion of board of commissioners, and the size of the board of directors have a significant positive effect on the company performance. Meanwhile, an institutional ownership has a significant negative effect on the company performance. The result also finds that capital structure can mediate the effect of managerial ownership, the proportion of independent board of commissioners and the size of the board of directors on the company performance company. However, it cannot mediate the influence of institutional ownership on the company performance.
\end{abstract}

Keywords: good corporate governance, corporate performance, capital structure

\section{Introduction}

The concept of good corporate governance arises in relation to principal agency theory, where the agent will have a difference interest with the principal. A conflict between principal and agent can be said as an agency problem. This agency problem must be managed with the hope to minimize losses to both principal and agent. The implementation of good corporate governance in a good company can enhance the confidence of the investors that they will get their investment capital back and receive a return on their investment (Cressy, Cumming, \& Mallin, 2010; Pamungkas, Ghozali, Achmad, Khaddafi, \& Hidayah, 2018). The implementation of good corporate governance can be divided into two ways: an internal mechanisms where the corporate's control is carried out internally in balancing the rights among stakeholders such as: managerial ownership, independent commissioner, board of directors and an external mechanism where corporate's control is done by including all parties outside of the corporate in controlling companies such as: institutional ownership (Iskandar, 2017; Jensen \& Meckling, 1976; Lozano, Martínez, \& Pindado, 2016).

The characteristics of companies in Indonesia that are going public are part of business groups. The form of a conglomerate business built from a family company is characteristic of medium and large companies in Indonesia. Developing countries do not yet have an advanced external capital market mechanism. So that the process of internal capital allocation through diversification becomes dominant, especially for large companies. So it is not surprising that the power of conglomerates is a very significant economic pillar in developing countries. There are several studies examining corporate governance with managerial ownership (Ghozali, Achmad, \& Pamungkas, 2019; Gugong, Arugu, \& Dandago, 2014), independent commissioners (Aggarwal, Schloetzer, \& Williamson, 2016), board of directors (Abor \& Biekpe, 2007; Fama \& Jensen, 1983) and institutional ownership (Gugong et al., 2014; Hersugondo, Pertiwi, \& Udin, 2019; Lozano et al., 2016) which indicated that a good corporate governance has a positive relationship with firm performance. In contrast, a finding from Alipour \& Amjadi, (2011); Mandacä \& Gumus, (2010) found that managerial ownership negatively affect the company performance, Allegrini et al., (2012) 
in his research found that the board of directors negatively affect the company performance.

A good corporate governance affects the company performance as a result of the reduced takeover by management in managing the cash flows which is expected to be distributed to investors (Black, Jang, \& Kim, 2006). The performance used in this empirical research is measured by an accounting basis, such as Return on Assets (ROA). ROA is measured by the ratio between net income and total assets (Chabachib, Yudha, Hersugondo, Pamungkas, \& Udin, 2019). From some empirical studies conducted by the previous researchers Aggarwal et al., (2016); Gugong et al., (2014); Lozano et al., (2016) they sololey related the corporate governance with the company performance itself, they have not considered the trade-off between the influence of the company and personal taxes, bankruptcy costs and agency costs.

According to Jensen \& Meckling, (1976) addressing the point that the conflict between agents and principals can be minimized by aligning their interests so it can lower the agency costs. The agency theory shows that capital structure can support to reduce the agency's costs. Empirically, this shows that the capital structure can be used as a supervisory mechanism against managers with the aims they do not act opportunistically and work in accordance with corporate objectives so that the company performance will increase, especially in companies with the weak corporate governance. Henceforth, in this study, the capital structure serves as a variable mediation between corporate governance and corporate performance.

The study on the relationship between corporate governance and capital structure was conducted by Sheikh \& Wang, (2012); Wen, Rwegasira, \& Bilderbeek, (2002) found the evidence that managerial and board size ownership positively affect the capital structure, while Anderson, Mansi, \& Reeb, (2004); Elzahar \& Hussainey, (2012) deduced that board independence and institutional ownership have a negative effect on capital structure. Based on the above description, there is a research gap in the previous research and in the previous researchers, they seemed have not linked yet the corporate governance with corporate performance which mediated by capital structure, thus this research will examine the influence of good corporate governance on company performance through capital structure.

\section{Literature Review and Hypothesis Development}

The agency problem will be indicates that the value of the company will be increase if the owner of the company can control the behavior of management so as not to waste the company's resources, both inside forms of investment that are neither feasible nor deep shape of shirking. Corporate governance is a system that regulates and controls the company is expected to provide and increase the value of the company to the para shareholders. Thus, application good corporate governance can be trusted increase the value of the company (Giroud \& Mueller, 2011; Li, 2014). Empirical researchers in corporate finance also consider firm size an important and fundamental firm characteristic, and, in many situations, observe a "size effect" firm size affects the empirical results (Coles, Li, \& Wang, 2018; Dang, Li, \& Yang, 2018).

Good Corporote governance in this study is proxied with managerial ownership, independent board of commissioners, board size and institutional ownership. Jensen \& Meckling, (1976) argued that agents may have a difference interest with the principal. This will potentially lead to conflict between agents and principals which is called as an agency problem. One effort that can be done to reduce the agency problem is to increase managerial ownership. This is because by a lot of managerial ownership, managers will feel possessing a company and will align the interests of managers with the principal so that a positive impact on company performance will happen afterwards. The management parties who have shares within the company tend to make strategies to improve the performance of the company. The finding from Gugong et al., (2014); Hu \& Zhou, (2008); Ongore \& K'Obonyo, (2011) showed that there was a positive and significant influence between managerial ownership and company performance so that it can be formulated a hypothesis as follows:

H1: Managerial ownership positively affects the company performance

When the conflict between agent and principal happens, the independent commissioner may lower the agency problem (Jensen \& Meckling, 1976). This is because an independent commissioner has no relationship with the board of directors, other board members and shareholders, and they are free from business relationships or other relationships that may affect their ability to act independently so as to monitor the behavior of managers. Thus, the more the number of supervisors the possibility of conflict of interest will decline and have an impact to improve company performance.

A research conducted by Allegrini et al., (2012); Das, (2017) saying that the board of independent commissioners have a significant effect on the performance of the company. The independent commissioners are able to influence 
the behavior of managers in an effort to improve company performance. The board of commissioners with more independent members tend to provide better monitoring of management policies to improve the company performance. Hence, it that can be formulated a hypothesis as follows:

$\mathrm{H} 2$ : The proportion of independent board of commissioners positively affects the company performance

The resource dependency theory, Pfeffer \& Gerald, (1978) suggested that companies rely on management to manage their resources to be a better company. The emphasis of the resource dependency theory is not how to use the resources, but rather how the resources are accessed and obtained. Pamungkas, Ghozali, \& Achmad, (2018) in his research found that the more the board of directors, it will make it more effective because each new board member has the expertise and an access in getting the resources needed by the company. In addition, the ability of the board in conducting supervision of the manager depends on how many directors in the company. The more the board of directors, the more resources owned by the company and it ultimately improves the company performance.

Abor \& Biekpe, (2007) in his research found that the larger proportion of the board of directors will perform better than the fewers, with the main reason they may have many skills to help company to make better decision. In encouraging broad monitoring (controlling bodies) conducted by multiplying the directors can be an important step in improving corporate governance and improving corporate performance (Hersugondo, 2019; Isgiyarta, Nugroho, Ratmono, Helmina, \& Pamungkas, 2019). So that, it can be formulated a hypothesis as follows:

H3: The size of board directors positively affects the company performance

The existence of institutional investors can reduce the problem of agency because of the institutional capacity to supervise and to director managers to make debt and dividend policies in favor of shareholders (Jensen \& Meckling, 1976). This may indicate that the greater institutional ownership, it will make the monitoring function to be better and also it can control the opportunistic behavior made by the managers. The higher the institutional ownership, it then will provide the greater incentives for managers to manage the company well and to improve the company performance (Andriana \& Panggabean, 2017).

Das, (2017) showed in his research that the control function of institutional ownership is crucial in improving company performance. The existence of institutional investors within the company can reduce the agency problems. The greater the institutional ownership, the stronger the control of the company so that the owners can control the behavior of manager to act in accordance with company goals that ultimately improve the company performance. The increasing in institutional ownership in the company will have an effect on the greater voice and the push of the institution to oversee the management process. Gugong et al., (2014) also found a similar result where an institutional ownership positively affects the corporate performance. So it can be formulated as follows:

H4: Institutional ownership positively affects the company performance

A great managerial ownership will reduce the agency problems as they can align the interests between managers and shareholders. The wide proportion of managerial ownership can align both managers and shareholders positions, so that it will act in harmony with the shareholders where it can reduce the agency problems (Jensen \& Meckling, 1976). In addition, the managers will directly feel the benefits and disadvantages of the decisions taken. To minimize the opportunistic behavior of the managers, companies can do a bond by increasing debt. In this case, debt as one of the capital structures used by managers to improve the company performance. This is in accordance with pecking order theory Myers \& Ridge, (2008) which stated that managers will choose to use a retained earning firstly, debt, and then a capital from external in form of the issuance of new shares. It means that debt is considered as one factor to be able to improve company performance ( $\mathrm{Li}, \mathrm{Lin}, \mathrm{Sun}, \&$ Tucker, 2018). So it can be formulated as follows:

\section{H5: Capital structure can mediate the relationship between managerial ownership and corporate performance}

Jensen \& Meckling, (1976) explained that an agency is a contract in which one or more principals use agents/managers to run the company's activities. The agency problem stems from the tendency of managers to act on their own behalf. As many independent commissioners, it will be able to minimize the agency problem because they do not have a relationship with the directors, other board members, and controlling shareholders, and they are free so that they will not have a power to affect their ability to act independently. Therefore, it will make the board of independent commissioner performs in a good way at monitoring function against the manager so as not to behave opportunistically and managers can manage the company's funds well to fit the interests of shareholders (Core \& Guay, 1999). As the monitoring function runs optimally, the company can also use bonding mechanism by means of debt to minimize the opportunistic behavior of managers so that the company can improve its performance. In addition, in the management of the company's financing, this is in line with the pecking order theory, Brealey \& Myers, (2008) where managers can use the source of funding from debt to improve their performance. Thus, it can be formulated a hypothesis as follows: 
H6: Capital structure can mediate the relationship between the proportion of independent board of commissioners and the company performance

Having a different interest between agent and principal, it leads to conflict called as an agency problem (Jensen \& Meckling, 1976). In minimizing the agency problem, the board of DIRectors has an important role. They are the board of the company in the management and they can make the decisions such as funding, the more board of directors it will avoid the sources of funding coming from outside so that it can lower the agency problem. This is in line with the pecking order theory, Myers \& Ridge, (2008) in which the managers will choose to use the retained earnings first, debt, and then the capital from external factor as the issuance of new shares. So it can be formulated as follows:

H7: Capital structure can mediate the relationship between the size of the board of directors and corporate performance

An institutional ownership has a role in minimizing the agency problems, this is because the large institutional ownership can perform better in monitoring functions to control the opportunistic behavior of managers in harmony with principal interests (Jensen \& Meckling, 1976). Thus the manager will reduce the debt and help to reduce the agency costs. In order to maximalize the supervision, the company can also do bonding by raising the debt to achieve a good corporate performance. According to Myers \& Ridge, (2008) managers can choose to use debt to improve company performance. So it can be formulated as follows:

H8: Capital structure can mediate the relationship between institutional ownership and corporate performance

\section{Method}

The object of this study is a non-financial company in the year of 2018 listed on the Indonesia Stock Exchange. Data obtained from Indonesia Stock Exchange by purposive sampling method. From the data on financial statements in 2018, it obtained the number of 393 companies and after the sample selected then it obtained samples as many as 120 companies. This study uses a path analysis with the following model:

$$
\begin{gathered}
\text { DER }=\beta 1 \mathrm{MO}+\beta 2 \mathrm{INDP}+\beta 3 \mathrm{DIR}+\beta 4 \mathrm{INTS}+\varepsilon 1 \\
\mathrm{ROA}=\beta 5 \mathrm{MO}+\beta 6 \mathrm{INDP}+\beta 7 \mathrm{DIR}+\beta 8 \mathrm{INTS}+\beta 9 \mathrm{DER}+\varepsilon 2
\end{gathered}
$$

In this case, DER (Debt to Equity Ratio) is the proxy of capital structure as measured by total debt divided by shareholder equity or personal capital as a mediation variable. MO (Managerial Ownership) measured by the percentage of total shares owned by management of the total shares of the company; INDP is the proportion of independent board of commissioners as measured by the number of independent board of commissioners divided by total board of commissioners; DIR is the size of the board of directors measured by the total members of the board of Directors and INTS is the institutional ownership as measured by the percentage of total shares owned by the institutional divided by the total shares of the company as an independent variable. ROA (Return On Asset) proxy from company performance measured by the net profit divided by total asset as dependent variable. The single biggest issue in this line of research is the endogeneity problem, which is the main reason the literature is largely mixed regarding the above two theories. In fact, researchers either use one or two simple methods to mitigate endogeneity issues or simply ignore the problem ( $\mathrm{Li}, 2016)$.

\section{Result and Discussion}

The sample in this study is a non-financial company in 2018 as mny as 120 companies listed on the Indonesia Stock Exchange. The descriptive statistics in this study can be seen in Table 1.

Table 1. Descriptive statistics on research variable

\begin{tabular}{cccccc}
\hline Variable & $\mathrm{N}$ & Minimum & Maximum & Mean & Std. Deviation \\
\hline Ownership Manager (MO) & 120 & 0,0100 & 49,0700 & 6,938583 & 10,1406757 \\
Independent Board of Commissioner (INDP) & 120 & 0,1429 & 0,8000 & 0,37484 & 0,1008086 \\
Board Size (DIR) & 120 & 2 & 13 & 4,90 & 2,080 \\
Institutional Ownership (INTS) & 120 & 24,4400 & 99,8500 & 68,169583 & 16,6230024 \\
Debt to Equity Ratio (DER) & 120 & $-4,9342$ & 8,7858 & 1,220911 & 1,4370408 \\
Return On Assets (ROA) & 120 & $-0,7842$ & 0,3371 & 0,014412 & 0,1046546 \\
\hline
\end{tabular}

This research uses a path analysis with SmartPLS software where the result of hypothesis can be seen in Table 2 and Figure 1. 
Table 2. The Result of hyphotesis testing

\begin{tabular}{|c|c|c|c|c|c|c|}
\hline & & Original Sample & Sample Mean & Standart Deviation & Standar Error & T Statistics \\
\hline $\mathrm{MO}$ & $\rightarrow$ DER & $-0,260257$ & $-0,257279$ & 0,017805 & 0,017805 & $14,617104^{* * * *}$ \\
\hline INDP & DER & $-0,015133$ & $-0,017011$ & 0,016080 & 0,016080 & 0,941108 \\
\hline DIR & $\rightarrow$ DER & 0,052684 & 0,054197 & 0,016184 & 0,016184 & $3,255334^{* * * *}$ \\
\hline INTS & $\rightarrow$ DER & $-0,183861$ & $-0,178674$ & 0,027668 & 0,027668 & $6,645350^{* * * *}$ \\
\hline DER & $\rightarrow \mathrm{ROA}$ & $-0,179395$ & $-0,178386$ & 0,013889 & 0,013889 & $12,915945^{* * *}$ \\
\hline MO & $\rightarrow \mathrm{ROA}$ & 0,046503 & 0,048587 & 0,014716 & 0,014716 & $3,160119^{* * *}$ \\
\hline INDP & $\rightarrow \mathrm{ROA}$ & 0,030332 & 0,030241 & 0,012675 & 0,012675 & $2,393128^{* * * *}$ \\
\hline DIR & $\rightarrow \mathrm{ROA}$ & 0,125924 & 0,125229 & 0,013244 & 0,013244 & $9,507946^{* * * *}$ \\
\hline INTS & ROA & $-0,031510$ & $-0,029914$ & 0,015548 & 0,015548 & $2,026605^{* * *}$ \\
\hline
\end{tabular}

Description: $* * *$ significant at $1 \%$

Ownership manager is measured by the percentage of total shares owned by management of the total shares of the company; Independent Board of Commissioner is measured by the number of independent board of commissioners divided by total board of commissioners; Board Size is measured by the total members of the board of directors and Institutional Ownership is measured by the percentage of total shares owned by the institutional divided by the total shares of the company as independent variables; Return On Assets is measured by the net income divided by total assets as dependent variable; and Debt to Equity Ratio is measured by total debt divided by shareholder equity as a mediation variable. Based on hypothesis test result in Table 2, it shows that managerial ownership has a significant positive effect on company performance, in other words, the managerial ownership has a direct effect on company performance. This is in line with the agency theory where one of the efforts undertaken to minimize agency problem is by increasing share ownership by managers. Thus it will align the interests of managers with shareholders who will then improve the performance of the company. Gugong et al., (2014); Hu \& Zhou, (2008); Ongore \& K'Obonyo, (2011); Utomo, Machmuddah, \& Pamungkas, (2019) in their research found that managerial ownership positively affects the company performance. The management parties that have shares within the company tend to make strategies to improve their performance.

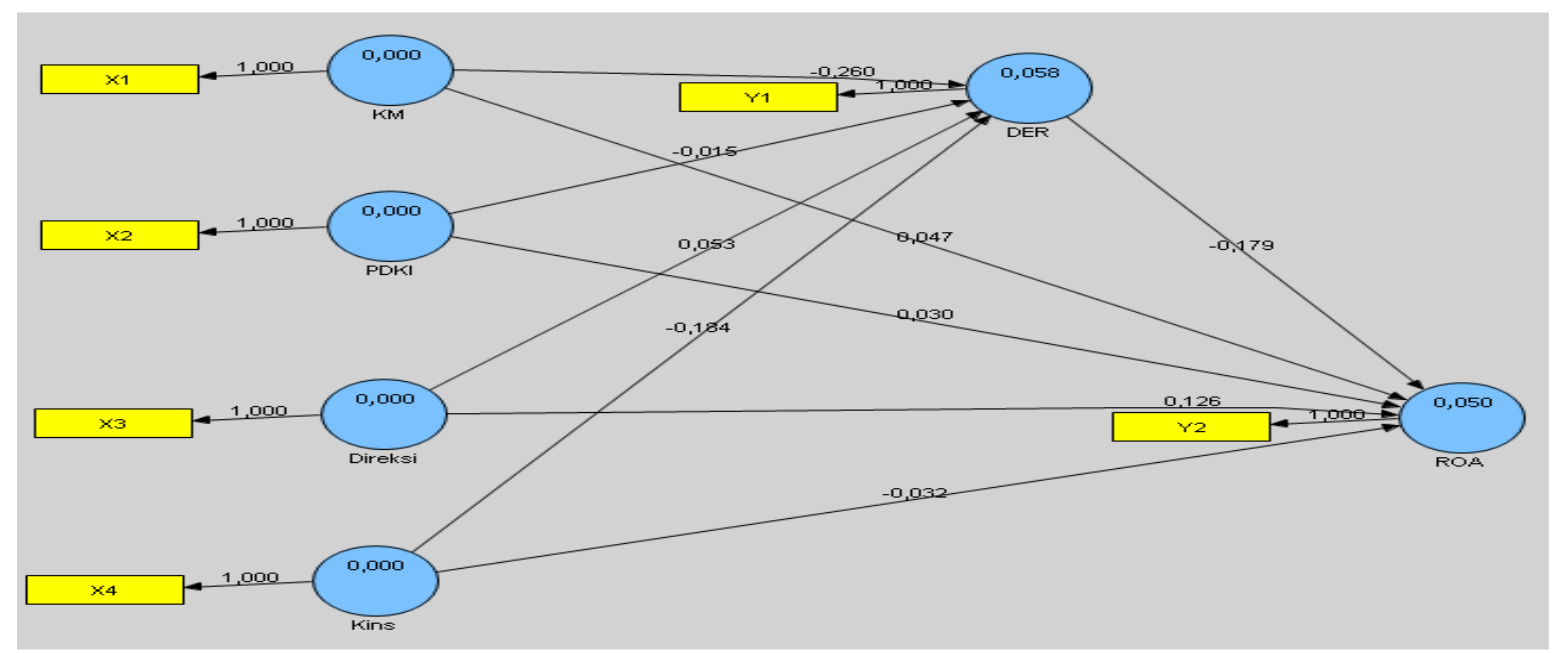

Figure 1. The result of hyphotesis testing

The result of hypothesis also shows that the proportion of independent board of commissioner has a significant positive effect on the company performance where it can also be said that the director influence of independent commissioners on the performance of the company. This is in line with the theory of agency as Jensen \& Meckling, (1976) suggested that the independent commissioners can lower the agency problems. This is because an independent commissioner has no relationship with the board of directors, other members of the board of commissioners and shareholders, and they are free from business relationships or other relationships that may affect 
their ability to act independently, thus thry can have a better monitoring to managers. So, the greater the number of supervisors the possibility of conflict of interest arises will be lower so as to improve the performance of the company. A research conducted by Allegrini et al., (2012; Das, (2017) found that independent commissioners are able to influence manager behavior in an effort to improve company performance. An independent board of commissioners with more independent members tend to provide a better supervision of management policies to improve the performance of the company.

Table 2 above also shows that the size of the board of directors also directly affects the company performance or there is a significant positive effect on the size of the board of directors on the performance of the company. The result of this research is in line with Resource dependency theory that company depends on management in managing its resources. The perspective theory of Resource dependency is not how to use resources, but rather how resources are accessed and acquired. The size of a large board of directors makes it more effective because each new board member has the expertise and access to obtain the resources needed by the company. The more the board of directors will be, the more resources the company owns and ultimately it can improve the company performance. Shahwan, (2015) in his research found that the more the board of directors it will make it more effective because each new board member has the expertise and access in getting the resources needed by the company. In addition, the ability of the board in terms of monitoring and controlling the manager depends on how many directors in the company. The more the board of directors will be the more resources the company owns and ultimately can improve the company performance. Abor \& Biekpe, (2007) in his research also found that the larger board of directors they will perform better than the fewer boards of directors because the larger boards of directors have many different skills to make better decisions.

Relating to the influence of institutional ownership on company performance, it shows that the results from the discussion do not support the theory. The results show that institutional ownership has a negative effect on company performance. From the non-financial company data as sample choosen, the proportion of institutional ownership has the source from the main investors or corporations and institutional investors outside of the corporation. The funding of $25 \%$ comes from institutional investors incorporated into one group, while the remaining $75 \%$ comes from institutional investors that have nothing to do with the company or outside of the group. This means that institutional ownership has no interest to a long-term corporate performance because many institutional investors come from outside that are not directly related to the company. It then makes the monitoring function performed by the institution does not work properly.

The results as listed in Table 2 show that capital structure can mediate the effect of managerial ownership, board size and institutional ownership on company performance or in other words managerial ownership, board size and institutional ownership affect indirectly to corporate performance through capital structure. This suggests that to prevent managers from behaving opportunistically, companies should maximize monitoring conducted by the board of directors and institutional owners and they also have to do bonding by increasing the debt and managerial ownership in order to achieve a high corporate performance. However, the results of this study outline that the independent board of directors do not directly affect the performance of the company through the capital structure. This means that capital structure can not mediate the influence of independent board of commissioners on the performance of the company. It may be said that the independent commissioners are not yet fully independent toward the board of directors so that supervision is not run optimally.

\section{Conclusion}

Based on the results of data analysis and the discussion, it can be drawn some conclusions as follows: first, the results of most research support the agency theory that is related to corporate governance influences which is proxied with managerial ownership, proportion of independent board of commissioners, board size and institutional ownership on company performance. Managerial ownership, the proportion of independent board of commissioners and board size have a significant positive effect on company performance, while institutional ownership has a significant negative effect on company performance. Second, capital structure can mediate the effect of corporate governance that is proxied by managerial ownership, the proportion of independent board of commissioners and the size of the board of directors to the performance of the company. However, the capital structure can not mediate the influence of institutional ownership on company performance.

The implication of this research findings is that the corporate governance with managerial ownership, the proportion of independent board of commissioners and the size of the board of directors have a pivotal role in improving the company performance, while institutional ownership has not given a big role in supervising the company performance. In addition, to minimize the agency conflicts between managers and principals, companies should implement a good corporate governance. In this case, they have to conduct monitoring mechanisms with the 
supervision by independent board of commissioners and board of directors and conduct bonding mechanisms with managerial ownership and increase the debt as a measure of capital structure so that managers do not take opportunistic action and focus on improving company performance only.

\subsection{Limitation}

The limitation of the research is that it is only conducted on non-financial companies in Indonesia Stock Exchange listed in 2018 so it can not be generalized to all companies. It is recommended for future research to expand the object of research, it is not limited only to non-financial companies listed in Indonesia Stock Exchange, and the future researcher can also add the companies listing in ASEAN countries and put the period of time of the research. In addition to adding another variable such as audit committee so that this study becomes far better than the previous one.

\section{References}

Abor, J., \& Biekpe, N. (2007). Corporate governance, ownership structure and performance of SMEs in Ghana: implications for financing opportunities. Corporate Governance: The International Journal of Business in Society, 7(3), 288-300.

Aggarwal, R., Schloetzer, J. D., \& Williamson, R. (2016). Do corporate governance mandates impact long-term firm value and governance culture?. Journal of Corporate Finance.

Alipour, M., \& Amjadi, H. (2011). The effect of ownership structure on corporate performance of listed companies in Tehran stock exchange: An empirical evidence of Iran. International Journal of Business and Social Science, 2(13), 49-55. Retrieved from http://ijbssnet.com/journals/Vol._2_No._13_Special_Issue_July_2011/6.pdf

Allegrini, M., Greco, G., Antonelli, G., Rivieccio, G., Moschera, L., Bachiller, P., Zattoni, A. (2012). Board Diversity and Investments in Innovation: Empirical Evidence from Italian Context. Journal of Management and Governance, 17(1), 1-27. https://doi.org/10.1111/j.1467-8551.2008.00591.x

Anderson, R. C., Mansi, S. A., \& Reeb, D. M. (2004). Board characteristics , accounting report integrity, and the cost of debt. Journal of Accounting and Economics, 37, 315-342.

Andriana, A., \& Panggabean, R. R. (2017). The Effect of Good Corporate Governance and Environmental Performance on Financial Performance of the Proper Listed Company on Indonesia Stock Exchange. Binus Business Review, 8(1), 1. https://doi.org/10.21512/bbr.v8i1.1757

Black, B. S., Jang, H., \& Kim, W. (2006). Does corporate governance predict firms' market values? Evidence from Korea. The Journal of Law, Economics, and Organization, 22(2), 366-413.

Brealey, M., \& Myers, S. C. (2008). Allen, Principles of Corporate Finance. McGraw-Hill.

Chabachib, M., Yudha, A., Hersugondo, H., Pamungkas, I. D., \& Udin, U. (2019). The role of firm size on bank liquidity and performance: A comparative study of domestic and foreign banks in Indonesia. International Journal of Economics and Business Administration, 7(3), 96-105.

Coles, J. L., Li, Z., \& Wang, A. Y. (2018). Industry tournament incentives. The Review of Financial Studies, 31(4), 1418-1459.

Core, J., \& Guay, W. (1999). The use of equity grants to manage optimal equity incentive levels. Journal of Accounting and Economics, 28(2), 151-184. https://doi.org/10.1016/S0165-4101(99)00019-1

Cressy, R., Cumming, D., \& Mallin, C. (2010). Entrepreneurship, Governance and Ethics. Journal of Business Ethics, 95. Retrieved from http://10.0.3.239/s10551-011-0848-3\%0Ahttp://search.ebscohost.com/login.aspx?direct=true\&db=buh\&AN=60 904460\& site $=$ ehost-live

Dang, C., (Frank) Li, Z., \& Yang, C. (2018). Measuring firm size in empirical corporate finance. Journal of Banking and Finance, 86, 159-176. https://doi.org/10.1016/j.jbankfin.2017.09.006

Das, S. K. (2017). Impact of Corporate Governance Mechanisms on Firm's Performance: A Study on Listed Conventional Banks. Asian Business Review, 7(1), 15-24. https://doi.org/10.18034/abr.v7i1.6

Elzahar, H., \& Hussainey, K. (2012). Determinants of narrative risk disclosures in UK interim reports. Journal of Risk Finance, 13(2), 133-147. https://doi.org/10.1108/15265941211203189

Fama, E. F., \& Jensen, M. C. (1983). Separation of Ownership and Control. The Journal of Law and Economics, 26(2), 301-325. https://doi.org/10.1086/467037

Ghozali, I., Achmad, T., \& Pamungkas, I. D. (2019). Determinants of fraudulent financial reporting and 
whistleblowing system: Applying theory of planned behavior. WSEAS Transactions on Business and Economics, $16,393-402$.

Giroud, X., \& Mueller, H. M. (2011). Corporate Governance, Product Market Competition, and Equity Prices. Journal of Finance, 66(2), 563-600. https://doi.org/10.1111/j.1540-6261.2010.01642.x

Gugong, B. K., Arugu, L. O., \& Dandago, K. I. (2014). The Impact of Ownership Structure on the Financial Performance of Listed Insurance Firms in Nigeria. International Journal of Academic Research in Accounting, Finance and Management Sciences, 4(1), 409-416. https://doi.org/10.6007/ijarafms/v4-i1/698

Hersugondo, H. (2019). Corporate Governance and Corporate Value: The Mediating Role of Investment Effectiveness based on Human Capital. Quality-Access to Success, 20(171).

Hersugondo, H., Pertiwi, S. N. A., \& Udin, U. (2019). Corporate Social Responsibility and Corporate Value: Evidence from an Emerging Economy, Indonesia. Calitatea, 20(172), 51-55.

Hu, Y., \& Zhou, X. (2008). The performance effect of managerial ownership: Evidence from China. Journal of Banking and Finance, 32(10), 2099-2110. https://doi.org/10.1016/j.jbankfin.2007.12.047

Isgiyarta, J., Nugroho, D. A., Ratmono, D., Helmina, M. R. A., \& Pamungkas, I. D. (2019). Budgetary participation on managerial performance: commitment organization, innovation perception, and job relevant information as mediating variable. Quality - Access to Success, 20(173), 48-53.

Iskandar, M. (2017). Perception of Capital, Profit and Dividends Affect the Stock Purchase Intention in Indonesia Public Company. Junior Scientific Researcher, 3(1), 9-18.

Jensen, M. C., \& Meckling, W. H. (1976). Theory of the Firm: Managerial. Journal of Financial Economics, 3, 305-360. https://doi.org/http://dx.doi.org/10.1016/0304-405X(76)90026-X

Li, F. (2016). Endogeneity in CEO power: A survey and experiment. Investment Analysts Journal, 45(3), 149-162.

Li, Z. F. (2014). Mutual monitoring and corporate governance. Journal of Banking \& Finance, 45, 255-269.

Li, Z. F., Lin, S., Sun, S., \& Tucker, A. (2018). Risk-adjusted inside debt. Global Finance Journal, 35, 12-42.

Lozano, M. B., Martínez, B., \& Pindado, J. (2016). Corporate governance, ownership and firm value: Drivers of ownership as a good corporate governance mechanism. International Business Review, 25(6), 1333-1343. https://doi.org/10.1016/j.ibusrev.2016.04.005

Mandacä, P., \& Gumus, G. (2010). Ownership concentration, managerial ownership and firm performance: Evidence from Turkey. South East European Journal of Economics and Business, 5(1), 57-66. https://doi.org/10.2478/v10033-010-0005-4

Myers, S. C., \& Ridge, B. (2008). CORPORATE.

Ongore, V. O., \& K'Obonyo, P. O. (2011). Effects of selected corporate governance characteristics on firm performance: Empirical evidence from Kenya. International Journal of Economics and Financial Issues, 1(3), 99-122.

Pamungkas, I. D., Ghozali, I., \& Achmad, T. (2018). A pilot study of corporate governance and accounting fraud: The fraud diamond model. Journal of Business and Retail Management Research, 12(2).

Pamungkas, I. D., Ghozali, I., Achmad, T., Khaddafi, M., \& Hidayah, R. (2018). Corporate governance mechanisms in preventing accounting fraud: A study of fraud pentagon model. Journal of Applied Economic Sciences, 13(2).

Pfeffer, J., \& Gerald, R. (1978). Salancik. 1978. The external control of organizations: A resource dependence perspective. New York: Harper \& Row.

Shahwan, T. M. (2015). The effects of corporate governance on financial performance and financial distress: evidence from Egypt. Corporate Governance (Bingley), 15(5), 641-662. https://doi.org/10.1108/CG-11-2014-0140

Sheikh, N. A., \& Wang, Z. (2012). Effects of corporate governance on capital structure: empirical evidence from Pakistan. Corporate Governance: The International Journal of Business in Society.

Utomo, S. D., Machmuddah, Z., \& Pamungkas, I. D. (2019). The effect of auditor switching and managerial ownership on fraudulent financial statement. WSEAS Transactions on Business and Economics, 16, 306-315.

Wen, Y., Rwegasira, K., \& Bilderbeek, J. (2002). Corporate governance and capital structure decisions of the Chinese listed firms. Corporate Governance: An International Review, 10(2), 75-83. 